\title{
Empathic Vision? War Photography, Ekphrasis, and Memory in Bosnian War Literature
}

\section{Introduction}

In "Shelter," one of the short poetic vignettes from his book Sarajevo Blues, a collection of poems and short prose fragments that he wrote during the siege of Sarajevo, the Bosnian poet Semezdin Mehmedinović notes:

I'm running across an intersection to avoid the bullet of a sniper from the hill when I walk straight into some photographers: they're doing their job, in deep cover. If a bullet hit me they'd get a shot worth so much more than my life that - at this moment - I'm not even sure whom to hate more: the Chetnik sniper or these monkeys with Nikons. For the Chetniks I'm just a simple target but these others only confirm my utter helplessness and even want to take advantage of it. In Sarajevo, death is a job for all of them. (1998b: 74)

The four-year-long siege of Sarajevo (1992-1995) attracted a lot of media attention. Although the proliferation of media images of the war greatly enhanced the international visibility of civilian suffering, photographs did not stop the war. It is hence not surprising that war photography and its aesthetic and moral effects occupy a prominent but controversial place in Bosnian war literature.

The quote from Mehmedinović suggests that the civil population did not necessarily perceive Western war photographers as allies. To the contrary: Mehmedinović not only calls them "monkeys with Nikons" but also compares them to the Serbian snipers who shoot at civilians from the hills surrounding Sarajevo. Moreover, they are almost worse than the "Chetniks" for whom a civilian is "just a target" - for the Western war photographers, the targeted civilians are a source of income, and in this respect, they, as it were, collaborate with or even depend on the Chetniks: if they succeed in photographing a victim while he or she is being shot, they will make even more money. ${ }^{1}$

1 Historically, the Chetniks were a Serbian nationalist military organization formed from detachments of the former Yugoslav army which, after the collapse of the Kingdom of Yugoslavia in 1941, continued to support the King. Initially formed to fight the Axis forces that had occupied and partitioned Yugoslavia, the Chetniks mostly ended up fighting the communist partisan

Ә OpenAccess. (C) 2020 Stijn Vervaet, published by De Gruyter. (cc) BY-NC-ND This work is licensed under the Creative Commons Attribution-NonCommercial-NoDerivatives 4.0 License. 
Mehmedinovićs evoking of the "shooting" metaphor in his description of the war photographer is not accidental; it is a metaphor that has often been used in the history of photography. Susan Sontag mentions Ernst Jünger as one of the first who used the shooting metaphor to discuss photography in direct connection with war (2003: 66-67). In his essay about the photographs by Kemal Hadžić, a photographer who fought in the Bosnian army, Mehmedinović himself played with the same metaphor, showing how different associations evoked by the metaphor could be linked to Hadžić's war photographs and biography as a war photographer (1998a: 5-11). However, more is at stake here. During the Bosnian war, Western media explicitly espoused a discourse of compassion and human rights, but on the ground, as Mehmedinovic claims, many photographers behaved as representatives of any for-profit company, not caring at all about the people they photographed. According to Philip Hammond, the "moral vocabulary" that reporters and intellectuals developed during the Yugoslav wars to encourage intervention in Bosnia and in Kosovo "has since been used as a standby justification for intervention anywhere from Afghanistan to Liberia" (2004: 175). Moreover, this "moralistic media consensus" was "driven by the need of Western societies to discover new moral purpose in the post-Cold war world" (Hammond 2004: 175). In other words, the Bosnian war became the seedbed of a new type of media discourse, including the production and use of visual images. ${ }^{2}$ Indeed, journalists' covering of the Bosnian war set a trend that would be soon called a "journalism of attachment" (Bell 1997), a notion coined by BBC journalist Martin Bell, who drew on his experience from the Bosnian war specifically to argue that journalists reporting on war should not remain neutral but side with the victims in order to instigate public action. ${ }^{3}$ As Lilie Chouliaraki has pointed out, there is an ambivalent "coexistence of requirements for the objective and the testimonial" in news coverage; that is, the idea that "news narratives [...] should appear both as objective information that respects the values of the news organization and as testimonial accounts that

forces led by Josip Broz Tito and even collaborated with Italian and German forces. In the Bosnian war, the term Chetnik was used as a derogatory name for Serbian paramilitary forces. 2 Certainly, the Vietnam War could to a certain extent be seen as a precursor; but the big difference was that that conflict unfolded and intensified largely as part of the Cold War and the struggle of the United States against the spread of communism.

3 For a critical investigation of Dutch journalists' reporting on the Bosnian war in precisely this way, see Ruigrok (2008). Based on the example of Marina Achenbach's On the Road to Sarajevo (Auf dem Weg nach Sarajewo), Oppen both offers a critique of German reporting and shows how an alternative form of journalism of attachment was possible: one that "recognises its own implicatedness, or attachment, is aware of its own positionality, but which does not abandon the quest to represent the conflict” (2009: 11). 
touch their publics into action" (2010: 306, 307). But - and Mehmedinović was deeply aware of this - cases that are covered by the news are also subject to what Chouliaraki calls “distinct 'pathologies' of witnessing: stories of suffering that focus on witnessing exclusively as a fact [and] diminish the emotive capacity of the news, 'annihilating' the human quality of the sufferer, whilst stories that focus on witnessing as horror, 'appropriating' the sufferer as someone who shares our own humanity, may lean towards a commodified sentimentalism that reduces witnessing to voyeurism" (2010: 306). It comes as no surprise, then, that the "pathologies of witnessing" that accompany Western media coverage of the Bosnian war, especially those triggered by war photography, are a recurrent topic in Bosnian war literature, in fiction as well as in non-fiction.

Mehmedinović is not the only Bosnian writer who tackled these issues a similar critique of foreign war photographers appears in work by other writers, such as in Nenad Veličković's collection of short stories The Devil in Sarajevo (Đavo u Sarajevu), which mentions an encounter with a Western war photographer similar to the one Mehmedinović describes; in Alma Lazarevska's "Death in the Museum of Modern Art" (Smrt u Muzeju moderne umjetnosti), whose narrator never talks about foreign photographers but mentions that "the reporters who come to the besieged city like taking pictures of ruins" (Lazarevska 2014: 99); while in Aleksandar Hemon's story "The Coin" from The Question of Bruno, the main character Aida works for foreign TV companies and has a love/hate affair with Kevin, an American cameraman who seems to be completely indifferent towards the horror he films. ${ }^{4}$

But does the dichotomy between "foreign reporters" and "local photographers" posed by so many Bosnian authors really hold, and if so, does it originate in the mercantile motives of (all?) international reporters versus the noble ethical goals of (all?) Bosnian photographers?

After all, there are many different positions and self-positionings possible within these two categories. In any case, this opposition begs for a closer investigation of how Bosnian authors of war prose describe or embed war photographs and to what effect. Does their embedding or describing lead the reader to different ways of imagining what the war was like, and if so, how? I suggest that the distinction made by the above-mentioned Bosnian writers is also, and perhaps foremost, related to the way in which photographers use the medium of photography.

4 For many of the authors and photographers discussed, the (auto)biographical side of their stories and photographs is a factor that should not be underestimated. 
This chapter explores the relationship between war photography, ekphrasis descriptions of photographs or mental images - and the memory of the siege of Sarajevo in essays, poems, prose vignettes, short stories, and novels by Semezdin Mehmedinović, Mira Otašević, Miljenko Jergović, and Alma Lazarevska. After exploring Mehmedinović's critique of "Western" war photography and its commodification of suffering, I show how Otašević invites the reader to ponder the link between the history of (artistic) photography and the role of media representations, how a short story by Jergović points out the potential of photographs to trigger storytelling, and how Lazarevska's focus on embodied knowledge increases a feeling of immersion in the story on the part of the reader, while her almost poetical use of metaphoric associations and involuntary memory leading to pre-war life at the same time slows down and defamiliarizes the reading process.

I argue that, by embedding images of war (real photographs or mental images) in a broader essayistic, poetic or fictional discourse, the authors under consideration move beyond discussions of photography as instances of "regarding the pain of others" (Sontag 2003). Using literature's ability to draw readers' attention to the embodied experience of living in a war as well as to the more insidious aspects of war, the works discussed suggest that the imaginative forces of literature and photography can lead to an increased self-reflexive positioning on the part of the viewer or reader.

\section{Towards a critique of (Western) war photography}

As Guido Snel has noted, ever since his war classic Sarajevo Blues, Mehmedinović's writing has "sought for ways to reclaim space for the written word at a time when it is increasingly challenged by an overpowering visual culture" (2016: 228). In Sarajevo Blues, "Mehmedinović's main preoccupation was to find an explanation for the failure of the outside world - Europe, the West - to truly identify with the city's [Sarajevo's] plight” (Snel 2016: 229). One of the main reasons for this failure to identify with civilian suffering in besieged Sarajevo is, according to Mehmedinović, due to the way in which media visually represent the siege:

Shots of the mass killing at Ferhadija circle the globe; pictures of the dead and massacred turn into an ad for the war. It doesn't matter that these people have names: TV translates them into its cool language, the naked image. The camera disembowels images of their psychological content to create information. And all the massacres that follow reproduce these 
same images. So the world can see what is going on here. But is this really possible when television sees right through the lack of compassion in human nature, just as long as tragedy doesn't hit home? The sense of tragedy arrived with the body bags wrapped in the American flag, and not before then, not through TV reports from Vietnam. Massacres happen to us, we empathize with our own tragedies. (1998b: 83)

This quote comes from a one-page essay in which Mehmedinović makes several claims. Firstly, mass-media coverage of a massacre such as that at Ferhadija (on 27 May 1992), he argues, turns people into "information," stripping them of their names and "psychological content" to the extent that images of all following massacres resemble each other. According to Barbie Zelizer (2010: 4-12, 18), such an understanding of the role of news images that highlights the photograph as "information relay," is a fairly traditional (mis)interpretation that understates the contingency of any visual image; moreover, the recycling or reproducing of images by media to which Mehmedinović refers is also typical of journalistic photography.

A second important claim he makes is related to the hoped-for result of journalistic war photography: the worldwide circulation of images of suffering does not necessarily result in the creation of an (international) audience that would feel sympathy with the victims. To the contrary, news media's use of shock effects can easily give way to "compassion fatigue" (see Garber 2004: 19; the concept was coined by Susan Moeller in 1999). Most audiences, Mehmedinović argues, are only concerned with their "own" tragedy - and here he draws a parallel with U.S. reactions to media reports about the war in Vietnam. Because of the way in which they are (mis)represented by the mass media, the lives of the Sarajevo civilians, he seems to suggest, are not "grievable lives" - lives that are considered valuable, and, hence, worth mourning (Butler 2009).

Mira Otašević's novel Zoe (Zoja) seems to echo some of Mehmedinović's concerns regarding war photography. The novel makes ekphrasis the explicit starting point of her novel. Narrating a highly fragmented history of modernist photography, each chapter of the book starts with an ekphrastic description of a photograph by famous photographers such as Berenice Abbott, Diane Arbus, Vivian Maier, and Henri Cartier-Bresson. Importantly, none of these photographs is included; that is, they are included only implicitly, through descriptions in words, surrounded by a frame. It is only in the last chapter that photographs are reproduced. This chapter is set in Sarajevo, where the main character, Zoja Klajn, meets Susan Sontag, who is preparing Beckett's Waiting for Godot with local actors. The novel depicts Sontag as an engaged intellectual: the narrator lets her cry out "Sarajevo is the Spain of our time! Martha Gellhorn claimed that one has to love the war to which one bears witness. Absurd and - correct!" 
(Otašević 2012: 96). Presenting Sontag as being unreservedly adored by the actors with whom she is staging Beckett's play and generally as a Western public intellectual who lives the life of all other Sarajevans under siege, the novel does not seem to problematize Sontag's engagement at any point. However, not all inhabitants of Sarajevo perceived Sontag's presence in Sarajevo in such an idealized way; some authors, such as Miljenko Jergović (Transatlantic Mail, 14), have noted her blindness to her own material and existential privileged position as compared to the living conditions of the local population. ${ }^{5}$ In this context, Lauren Berlant's definition of compassion as "an emotion in operation" seems to be relevant: "in operation, compassion is a term denoting privilege: the sufferer is over there" (2004: 4, original emphasis).

More disturbingly, Otašević's final chapter contains some of the iconic news photographs of the siege of Sarajevo that circulated all over the world - some of the images to which Mehmedinović refers: people crossing the street or intersections running to avoid being an easy target for snipers, people queuing for bread and water, killed adults and children on the city's asphalt. One reason the author included those photographs, some of which are quite shocking, could be the wish to make a political statement. As the book was published in Serbia, where mainstream public and political opinion still does not acknowledge the country's ugly role in the wartime destruction of Bosnia, those photographs could be interpreted as a warning: "Do not forget the facts! - This really happened.” As Otašević is also a theater director and playwright, one of the sources of inspiration that comes to mind is Brecht. However, her use of photographs here does not, in my view, lead to a sophisticated process of Verfremdung on the part of the reader. The photographs are not really embedded in the narration, but seem to function as mere illustrations of the narrator's descriptions of wartorn Sarajevo, turning the pages in question into a distressing collage that reiterates the cheap and quickly saturating shock effect that characterized much of the international news media's reporting on the Bosnian war.

At the end of the novel, Zoja - a photographer herself - decides to visit the tunnel that connected the besieged city with the outside world. The tunnel was dug manually under the airport and was approximately 800 meters long; it was constructed because the UN, which controlled the airport, denied citizens of Sarajevo permission to leave or enter the city. Ivana Maček, an anthropologist who did field research in Sarajevo during the war, notes that "before the tunnel was

5 For a discussion of Sontag's role as a Western public intellectual in Sarajevo during the war, as well as reactions by local authors such as Jergović and Mehmedinović to her presence and engagement in Sarajevo, see Snel (2016: 229-231). For a thorough discussion of Sontag's staging of Waiting for Godot in besieged Sarajevo, see Abazović (2015). 
dug, Sarajevans had to run across the runway hiding from the UN searchlights and the hail of bullets from Serbian snipers to reach the road into and out of Sarajevo" (2009: 27). Delighted to see that the tunnel really exists, Zoja starts running over the Sarajevo airport landing strip:

The boy shouts behind me. I don't hear him. I run straight towards the landing strip of the airport, despite the prohibition. An unexpected, violent and sharp pain throws me down. [...] In the last gleam of consciousness, I clearly see that someone photographs me. (Otašević 2012: 102)

The novel ends with the realization of the fear faced and expressed by Mehmedinović: the narrator is shot and photographed at the very moment of dying. She is killed and at that very moment turned into a piece of information, into a commodity with which someone will earn money. The chapter's - and the novel's ending seems to suggest that the history of artistic and engaged photography ends with the reduction of the art of photography to the mercantile work of war reporters. By setting up a dichotomy between media photography and artistic photography, Otašević's novel does not seem capable of escaping some of the pitfalls that Chouliaraki and Mehmedinović mentioned, but she might help resolve the dichotomy that Mehmedinović put forward in his texts: that between foreign and local photographers.

\section{Bosnian war photographers: Slowing down perception}

Mehmedinović contrasts foreign and domestic photographers and highlights the moral integrity of the Bosnian photographers, because they do their work without getting paid for it, amongst other reasons:

The photographers of Sarajevo - as opposed to their colleagues who come from abroad to collect their fees from dailies, weeklies and art magazines by trading in death - are the only chroniclers of war in this city; they run out of film and supplies and get no compensation for their work. This doesn't make them any different or their job more distinguished than that of surgeons, for instance, or firefighters. But their engagement is marked by an intellectual morality, something so rare in our parts both before and during the war. (1998b: 57)

Certainly, we have to take seriously the emotional reaction of people who were confronted with the (well-documented) ugly side of Western media reporting 
on the conflict. ${ }^{6}$ But we have, at least theoretically, to allow for the possibility that there were foreign photographers who took their task to witness seriously while also taking their own implicatedness with equal seriousness. ${ }^{7}$ At the same time, the question remains whether someone looking at a war photograph, not knowing its history, could tell whether the photograph was made by a Bosnian or a foreign photographer. ${ }^{8}$ Calling local Sarajevan photographers "the only chroniclers of the war" seems to imply that Mehmedinovic nevertheless believes in the need and sense of documenting and collecting evidence, but also that there are ways of photographing human beings caught by war that are qualitatively different from those of war reporters.

Three Sarajevan photographers figure quite prominently in Mehmedinović's work: Kemal Hadžić, Mladen Pikulić, and Milomir Kovačević. He mentions all three of them in his prose vignettes in Sarajevo Blues and also wrote an accompanying text for an exhibition by Kemal Hadžić (Mehmedinović 1998b). But how can we recognize and describe the moral quality to which Mehmedinović refers in a specific photograph? (And is getting no compensation a criterion to define someone's morality?) And if this "intellectual morality" can be isolated and formally described, is it something that would be characteristic of Bosnian photographers only? As Andrea Lešić has pointed out, Kovačević uses

specific methods of inserting the viewer into the picture, of working with the subject as an act of collaboration, of juxtaposing series of similar and contrasting images, of framing and filtering the image shown, and of presenting what is shown as an art-historical reference: all of these for Kovačević have been the means of slowing down the process of perception of what is shown, of preventing merely a shocked, knee-jerk reaction, of making sure the viewer asks questions of the photograph that lead to a reaction not just of human sympathy, but also to an active understanding of the circumstances, the broader context, to which the depicted scene refers. (2016: 141-142, emphasis added)

Even though Lešić refers to Shklovsky's concept of defamiliarization (ostranenie) only in a footnote, this reference is crucial to her reading of Kovačević's work. In her commentary on her recent translation of Shklovsky, Alexandra Berlina re-

6 The discussion could also, at least to some extent, be related to the question of who has the right to represent someone's trauma. The strong division between victims, bystanders, witnesses, and vicarious witnesses is an issue that appears time and again in discussions of historical or collective trauma; for the Holocaust, see Rothberg (2009); for Hiroshima and Nagasaki, see Auestad (2017).

7 On the notion of the implicated witness, see Rothberg (2013).

8 To test this, a detailed analysis of the "control group" - photographs made by Western media reporters - would be needed, something that was impossible to do within the limits of this essay. 
minds us that, although Shklovsky used ostranienie mostly related to "language" and "readers," "he also refers to film and sometimes visual arts, and seems to be assuming a similar distinction between images as sources of information and images as art" (Shklovsky and Berlina 2017: 23). "Slowing down the process of perception" is indeed important here: as Shklovsky writes in his much-quoted text "Art, as device":

The goal of art is to create the sensation of seeing, and not merely recognizing, things; the device of art is the "ostranienie" of things and the complication of form, which increases the duration and complexity of perception, as the process of perception is its own end in art and must be prolonged. Art is the means to live through the making of a thing; what has been made does not matter in art. (Shklovsky 2017: 80)

Much of what Lešić notes about defamiliarization in Kovačević’s work also applies to Hadžić's war photographs. For example, one of his photographs shows a recent cemetery on which one of the gravestones carries the inscription "Kemal Hodžić, 1950-1992" (Hadžić 1998: 87) - as if suggesting to the reader that the grave inscription might have read "Kemal Hadžić," giving a hint that the grave on the photograph could just as well have been the photographer's (or, for that matter, the viewer's) own grave. Kovačević's photographs sometimes include the shadow of the photographer, for example in the photograph showing the killed journalist Željko Ružičić lying on the ground (Kovačević 2012, photograph no. 76). ${ }^{9}$ As Lešić points out, the shadow could be "read metaphorically as the shadow of death [...] but it can also be seen as the device which forces the viewer into the position of the photographer as a direct witness" (2016: 142). By integrating a reference to the photographer into the depicted setting, the photographs invite the viewer "to live through the making of a thing," thus "de-automatizing things" (Shklovsky 2017: 80, 81). One of the effects of this is, as Lešić has pointed out, that "the use of the shadow disables our desire to gaze away, or just to feel a generalized sympathy; we have to look, and imagine what if it were us in that situation" (2016: 142).

9 The photograph of Željko Ružičić has the caption “Željko Ružičić, journaliste à Radio Sarajevo, tué par une bombe quelques instants après m'avoir annoncé qu'il avait enfin obtenu la permission de rendre visite à sa famille à Zagreb, 2 février 1992": "Željko Ružičić, journalist at Radio Sarajevo, killed by a bomb a few moments after I told him that he finally had obtained a permission to pay a visit to his family in Zagreb, 2 February 1992"; other photographs with the photographer's shadow include photograph no. 108, “Autoportrait devant la CEDUS, au 44 de la rue Titova où j’ai habité avec Mladen, Nermin et Fićo jusqu'en septembre 1992, avant de déménager à Sloga": "Self-portrait in front of the CEDUS, 44 Tito street, where I lived with Mladen, Nermin and Fićo until September 1992, before moving to Sloga.” 
In one way or another, many of Hadžić's and Kovačević’s photographs trigger the imagination of the viewer, urging him or her to linger rather longer than usual on the image and inviting him or her to ponder what it shows, as well as the context in which it was produced. A photograph by Hadžić shows a large UN tank in front of a completely destroyed skyscraper; beneath the open door of the vehicle, we see two human legs in soldier boots, but not the rest of the body, nor what the soldier is doing (Hadžić 1998: 22). The UN vehicle seems to appear as a tank with legs, a kind of friendly anthropomorphic animal, one eye closed, the others half-open, protecting itself against the sharp sun. At the same time, the image could be read as a metonymy for the presence of the UN in Sarajevo: while their declared mission was to protect the city's citizens, they often had to hide themselves from the heavy shelling of the city by Serbian troops from the surrounding hills. One of Kovačević's photographs shows a destroyed tram, covered by rubbish that, due to the perspective from which the photograph was taken, turns it into the shape of an angel-like figure (Kovačević 2012, photograph no. 80).

Some photographs also point out the insidious sides of war, such as the photographs showing two old men working on a parcel of ground in the midst of the city (Hadžić 1998: 77). By a viewer unaware of the place and time where the photograph was taken, this image could have been interpreted as a very quotidian scene: two men working in their vegetable garden on a sunny day. But in the context of the whole book, the viewer might as well wonder about the peculiar location the men had chosen for their garden - in the midst of apartment blocks in an obviously very urban part of the city - and perhaps arrive at the conclusion that cultivating a garden did not amount to a hobby but rather a way of surviving in Sarajevo under siege. By including the signature of the photographer into the image, by activating the imagination of the viewer, the war photographs of Kemal Hadžić and Milomir Kovačević defamiliarize images of war and slow down the viewer's gaze.

By fostering imagination on the side of the viewer, Kovačević's and Hadžić's photographs seem to achieve something more than "prolonging the process of perception": they also draw the viewer into the world of the photograph. In doing so, Hadžić and Kovačević require the viewers to reflect upon their own position as a viewer of an image of war suffering or destruction and to ponder the historical context in which the photograph was taken. In imposing such demands on the viewer, Kovačević and Hadžić engage in what Ariella Azoulay has called the "civil contract of photography," as their work creates a contract of "partnership and solidarity" that evolves from the triangular relationship between the three parties involved: "the photographed person, the photographer, and the spectator" (2008: 22-23). Thus, they seem to be giving back agency to 
those portrayed, or, at the very least, to redirect the way(s) in which audiences relate to the human beings (objects, buildings, spaces) represented in a war photograph. This slowing down/prolonging of the reader's perception is also characteristic of certain literary works dealing with the siege of Sarajevo. In the next section, I will explore how the link between prolonging the duration of perception and imagination is also pointed out in a short story by Miljenko Jergović, and then move on to demonstrate how short stories by Alma Lazarevska simultaneously draw the reader into the narrative and keep her at bay, achieving an effect of estrangement on the reader.

\section{The story behind the picture: Ekphrasis and imagination in Bosnian war fiction}

Miljenko Jergović’s story “The Empty Bird Cage” ("Pusta krletka za ptice”) published in Sarajevo, Map of a City (Sarajevo, plan grada) does not imply the same distinction between news photographs and artistic photographs that is at the heart of Mehmedinović's argument, but instead focuses on the imagination triggered by any photograph. The story opens as follows:

With that photograph, which was first published in Oslobođenje and later also in many newspapers all over the world, the war started. Before the war, it could not have happened that something was published in Oslobođenje and that the whole world would be interested in it. (Jergović 2015: 224)

The opening lines evoke a narrator (who is actually a kind of anthropomorphized city telling stories about his past to a 'you' that greatly resembles Jergović, or his fictional alter-ego) who either shows an image to his collocutor or talks to him about a well-known image: "with that photograph, the war started." The narrator's description of the photograph is actually rather brief, and more focused on imagining what happened before the photograph was taken than on what is actually caught in the image and how it is caught:

In the image are people, they had run out their house that just had been set on fire. A grenade that had fallen on the roof and the dry, wooden attic flared up and all four floors burned down. [...] Running out of the house, the inhabitants took what they could find. Or they took that which a person considers the most important when they wake him up unexpectedly, or when they tell him that he's got left maximum seven moments of his life in his apartment. [...] That's why the woman, running out of her flat, took an empty bird cage with her. That preposterous, empty bird cage [...] made this photograph so 
good, unforgettable and important, that with it, one era ended and another began. (Jergović 2015: 224)

Taken at the end of April or beginning of May 1992, the photograph becomes a symbol of the beginning of the war to the narrator. The next day, "newspaper readers all around the globe would watch her picture, wondering about the cage she held in her hand" (Jergović 2015: 231). Jergović writes that it is the detail in the photograph that triggers the imagination of viewers that makes a photograph stick; and that this imagination, in turn, could give birth to a true war novel about Sarajevo:

That which each of them thought at that moment [while looking at the photograph] and how they would explain to themselves and their near ones why this unknown woman from Sarajevo, running out of the flames, had taken with her an empty bird cage - that would have been the best war novel about Sarajevo, which would, in several thousands of installments, happen from Rio de Janeiro to Vladivostok, around the whole world. (Jergović 2015: 231)

By closing the chapter in this way - after delving into the history of the two streets at whose corner the famous photograph was taken - Jergović's narrator touches upon the link between defamiliarization and imagination, but apart from its narration in the second person, the story itself plays with neither of them, instead reading as a rather dry historical chronicle of Sarajevo.

In their insightful reading of the link between immersion and defamiliarization, which are traditionally seen as opposites, Anderson and Iversen argued that "the experiential emphasis associated with immersion and the more reflective stance associated with defamiliarization in our making sense of narratives are intertwined cognitive phenomena" (2018: 578). Along these lines, they also propose to understand Shklovsky's concept of ostranienie more broadly - as a scalar process, so to speak:

while defamiliarization describes reading experiences that differ from that of feeling transported into another world, it does so by offering different possibilities, some leading back to a more real reality, some leading to experiencing and appreciating the artwork's metaperceptional laboratory, and others again pushing the reader to experience not the reality but the unreality of what lies beyond the text. (Anderson and Iversen 2018: 582) ${ }^{10}$

10 Robinson's "somatic reading” of Shklovsky (2008) can be seen as a predecessor of the current interest in linking Shklovsky to cognition. 
A number of cognitive studies have foregrounded the embodied nature of immersion (for a good overview, see Anderson and Iversen 2018: 572-579). These insights help us understand how Alma Lazarevska's story(telling) works. In what follows, I will look at a story by Lazarevska that invites the reader to think through the tension or relation between imagination and defamiliarization. Lazarevska is one of the finest prose-writers of contemporary Bosnian-Herzegovinian literature, but unlike what was the case with her male colleagues Mehmedinović and Jergović, whose work was quickly translated into English and German, it took a long time for her work to be translated, which explains the relatively small amount of attention it has received outside former Yugoslavia. Lazarevska's story "Death in the Museum of Modern Art” (Smrt u Muzeju moderne umjetnosti, 1996), from the collection of short stories with the same title, opens in medias res with the question "How would you like to die?" The question is asked by someone who, as the story proceeds, turns out to be the narrator's partner, who reminds her that she should fill out the questionnaire they had received from an American magazine, together with 98 other inhabitants of Sarajevo under siege. All interviewees had previously been photographed at a site in the city:

On the little table in front of us lay a photograph of me. Taken in front of the ruins of the old hospital. The reporters who come to the besieged city like taking pictures of ruins. The hand I write with was still unharmed then but I had thrust it deep into my pocket. I had drawn my neck and hunched my shoulders, as though I was cold or uncomfortable. It seemed that I was stepping out of the photograph. Or should one say: stepping down? (Lazarevska 2014: 99)

The narrator's ekphrastic description of the photograph zooms in on the material setting (the ruins) and on her own bodily position that suggests that she was cold and uncomfortable. At the same time, her reading of the photograph directs the reader's attention to the sensory perception that she has now: to the pain of her injured hand, which prevents her from writing the answers to the questionnaire herself. The detailed description not only slows down the perception of the reader, but also seems to draw her into the story and closer to the narrator.

As Guillemette Bolens has argued, textual references to bodily movements and sensations trigger "sensorimotor perceptual simulations" in the reader that invite her to adopt the position of the narrator (Bolens 2012: viii; on sensorimotor response, see also Spolsky 1996). But even though "kinesthetic empathy," an act of internal perceptual simulation that enables us to understand and to a large degree infer another person's intentions, emotions, or state of mind (Bolens 2012, ch 1: 3, 6, 13, 18, 40) might enable or increase the reader's identification with the narrator or protagonist of the story, the form of perspective-taking - 
or readerly empathy - that Bolens describes is still several steps removed from social empathy ("sympathy" or "compassion," the lack of which Mehmedinović criticized in Western media reporting on the Bosnian war). Importantly, "empathy" can mean very different things - in colloquial speech, it is often used as a synonym for sympathy, fellow-feeling or altruism, but it actually stems from the field of aesthetic theory, from where it moved to psychology - a translation of the coinage Einfühlung, it originally described "a spatial understanding of forms" in art. ${ }^{11}$ The question of whether readers' responses to narrative lead to empathy as pro-social behavior is still being tested in empirical literary studies (see, for example, Koopman 2015, 2018). At the same time, a new branch of embodied narratology is developing that "brings to the fore the role of the body in shaping and reading narratives" and "places an emphasis on bodily experience as the meeting place of bodily states and perceptions [...] and the body's cultural reflections and images" (Caracciolo et al. 2016: 437). ${ }^{12}$ Lazarevska's story can be read in this vein.

Lazarevska also uses some narrative techniques that counter or even dispel the immersive effect. The narrator's evoking of her embodied experience of life during and before the war (e.g., in her reading of her own photograph but also in other places in the text) is in sharp contrast to the use and intended afterlife of the photographs by the magazine: "The answers, illustrated with our photographs, would be published in a luxurious magazine with shiny covers. Part of the edition would be kept in the Museum of Modern Art in New York. [...] What did they want from us?" (Lazarevska 2014: 100). Urged by her partner to give a response to the question "How would you like to die?," she replies "At Kristina Verček's!" (Lazarevska 2014: 101). The narrator then associatively harks back to her memories of pre-war Sarajevo in a way that disrupts narrative progression, at the same time drawing the reader's attention to the constructed nature of the story and of memory. Kristina Verček was a cosmetician who had a popular column in the newspaper where the narrator worked as a proofreader. Verček had the habit of inserting in her column the sentence "It is well known that everyone wants to live long, not grow old." When the narrator discovers that the sentence is being repeated, she on one occasion purposely changed the final three words of the column into "not die," prompting Verček to invite her to a free treatment. Her partner's question "Are you afraid of death?" evokes in her

11 For a genealogy of empathy, see Weigel (2017). For the relation between compassion, sympathy, and empathy, see Garber (2004). For an exploration of the link between research on empathy in neurosciences and in literary studies, see Lux and Weigel (2017). For the concept of empathy in cognitive literary studies, see Caracciolo (2014, Ch 5.3.3).

12 See also essays in Kukkonen and Caracciolo (2014). 
a series of involuntary memories of situations in which she felt overwhelmed by feelings of horror and anxiety (with her mother at the dentist) as well as of cases in which she was called upon to do something she didn't feel like doing (the usual question "Who wants to come first?" at a collective medical screening in primary school; an impatient shop assistant hurrying her to make up her mind in a shoe shop). For it is those feelings - being compelled to answer or act when you don't feel like doing so, and a feeling of horror emerging in reaction to this interpellation - that the question from the magazine elicits in her. Moving back to her treatment at Verček's, she recalls that while they were reclining with the mask on their face, the woman lying next to her said: "It would be good to fall asleep like this” (Lazarevska 2014: 114).

This is, then, what she lets her partner write in answer to the question: "In my sleep.” The association between beauty mask and death mask becomes clear in the story, and so is the line that runs from being treated by the magazine as a commodity to being buried alive in the MOMA. Later, when the first copies of the magazine reach the still-besieged city, the narrator muses: "Maybe one should not answer such questionnaires any more, even with the promise of the appealing possibility that our face, photographed, will be displayed to the gaze of the whole wide world. [...] and afterwards those answers lie like involuntarily purchased shoes in a wardrobe” (Lazarevska 2014: 121). The story ends, again, with a strong sense of embodiment:

Besides, the hand I write with has healed. If any new questions should arrive, I shall write my answers myself. I'm writing all of this with my own hand. I have placed the Times Atlas of World History under the sheets of paper. It is night. Tonight, in the Museum of Modern Art in New York, the answer extorted from me keeps me vigilant. (Lazarevska 2014: 122)

However, Lazarevska's story does more than criticize the commodification of human (hi)stories of war suffering that is often a corollary of commercial war photography. And she moves one step further than Jergović by not only telling the story behind the picture and triggering the imagination of the viewer but also weaving a whole story out of a complex web of memories (mediated by metaphoric associations) from pre-war life relating to embodied feelings of coercion, horror, and anxiety. In Lazarevska's work, readerly empathy is not triggered by images of suffering (or their realistic and detailed descriptions), but by the embodied cognition and perception at work in the story: the reader's understanding of how the protagonist feels is fostered by the detailed descriptions of her tactile and corporeal experience. The story "Death in the Museum of Modern Art" (as well as the other stories in the collection with the same title) depicts a life in the "city under siege" that is in stark contrast with the culture of shock- 
ing media images; they both defamiliarize mainstream views of war experience and slow down the narrative significantly. Do they increase empathy in the reader, and is it precisely empathy from the reader that her stories are after? As Ann Jurecic wrote, perhaps we should put more modest claims on narrative as a stimulus for empathy: "literature" - and photography, we could add - "matters not because it changes our brains, hearts, souls or political convictions, but because the practice of reading literature slows thought down" (2011: 24). Perhaps more importantly than triggering social empathy in the reader, Lazarevska's stories invite us to rethink the limits of empathy, the constructed nature of memory, and the role of narrative in both.

\section{Conclusion: Empathic vision}

All the authors and photographers whose work has been discussed above either experienced the siege of Sarajevo themselves or had friends and family living there. Confronted with the often ethically problematic sides of the intense media coverage of the siege of Sarajevo, they offered a sustained critique of the ambivalent role of (Western) news photography in representing human beings affected by war. The different ways in which authors and photographers use and reflect upon photography/ekphrasis related to the siege of Sarajevo can be seen as different levels of criticism, ranging from a political critique of the commodification of images of suffering to the photographic and narrative use of strategies of defamiliarization and immersion that invite the reader to rethink empathy with victims of war-torn areas.

I examined, first, how Mehmedinović and Otašević's prose offers a critique of news media's commodification of Sarajevo's suffering civil population, and singled out some of the contradictions in their thinking about and use of photography. In a second step, I briefly discussed how and why Mehmedinović perceives the work of Bosnian war photographers such as Milomir Kovačević 'Strašni' and Kemal Hadžić as an alternative form of war photography and presents their work as an ethical antidote to the media images produced by international war reporters. I have argued that rather than a dichotomy between foreign and local photographers, what characterizes their work is a tendency - also pointed out by Lešić (2016) - to slow down the perception of the viewer, a process that can be described in terms of Shklovsky's ostranienie (defamiliarization). In the third part of this chapter, I looked at ekphrasis - descriptions of photographs or mental images - in a short story by Alma Lazarevska, whose narrative techniques highlights the narrators' embodied experience of the war, combining immersive and defamiliarizing strategies. 
Mehmedinović's criticism of TV and news reporters' approaches to the inhabitants of the besieged city, unscrupulously hunting for shocking photographs of human suffering and turning those images into a commodity, lays bare some of the sore points characteristic of what Chouliaraki (2010) has called the "pathologies of witnessing" - the tension between objective (and objectifying) reporting and a more empathetic response. At the same time, Mehmedinović doubts the possibility that images of suffering can affect international audiences and instigate them into action, as each public is occupied with "their own" victims.

Instead, he values the work of Bosnian war photographers, such as Kemal Hadžić and Milomir Kovačević. Even though they do not shy away from showing images of death and destruction, rather than just shocking the viewer, the photographs by Hadžić and Kovačević aim mostly to trigger the imagination of the viewer as a precondition for understanding human trauma; they defamiliarize viewers' perception of war and urge them to contextualize the destruction, death, or suffering that is depicted. Drawing the spectator into the picture, their photographs reconfigure the relation between the depicted (suffering) subject or (destroyed) object, the photographer, and the audience (cf. Azoulay).

What Mehmedinović values in the photographs of Kemal Hadžić and Milomir Kovačević, it seems, are precisely those aspects that photography has in common with fiction. The ways in which works of fiction deal with war photography show that literature, not unlike the photographs of Hadžić and Kovačević, aims to give back agency to the subjects in the picture; at the same time, by contextualizing the war against the backdrop of which the (fictional) life stories are set, literary works act against depoliticizing trauma. Otašević invites the reader to ponder the link between the history of (artistic) photography and the role of media representations; Jergović's short story points out the potential of photographs to trigger storytelling; Lazarevska's focus on embodied knowledge increases a feeling of immersion in the story on the part of the reader, while her almost poetical use of metaphoric associations and involuntary memory leading to pre-war life at the same time slows down and defamiliarizes the reading process. If ekphrasis makes photographs concurrently both strange and familiar, then the same could be said about the effect literature has on the memory of the siege: narrative fiction both immerses the reader in and defamiliarizes her from the story that is told.

\section{Acknowledgments}

I am grateful to the editors of this volume, as well as to Reiko Abe Auestad, Alexandra Effe, Olivia Fialho, Ylva Østby, and Rolf Reber of the research group Liter- 
ature, Cognition and Emotions (University of Oslo) for their helpful comments on earlier versions of this chapter.

\section{Work cited}

Abazović, Dina (2015) Waiting for Godot in Sarajevo, 1993: Susan Sontag's War Production of Samuel Beckett's Play, MA thesis (Stavanger: University of Stavanger). <https://brage.bib sys.no/xmlui/handle/11250/286647> (accessed 7 March 2019)

Anderson, Miranda and Stefan Iversen (2018) "Immersion and Defamiliarization," Poetics Today 39.3, pp. 569-595.

Auestad, Reiko Abe (2017) "Ibuse Masuji's Kuroi Ame (Black Rain 1965) and Imamura Shohei's Film Adaptation, Kuroi Ame (Black Rain 1989)," Bunron - Journal of Japanese Literary Studies 4, pp. 1-19.

Azoulay, Ariella (2008) The Civil Contract of Photography (New York: Zone Books).

Bell, Martin (1997) “TV News: How Far Should We Go?” British Journalism Review 8.1, pp. 7-16.

Berlant, Lauren (2004) “Introduction: Compassion (and Withholding)," in Lauren Berlant (ed.) Compassion: The Culture and Politics of an Emotion, (New York: Routledge), pp. 1-13.

Bolens, Guillemette (2012) The Style of Gestures: Embodiment and Cognition in Literary Narrative (Baltimore: Johns Hopkins University Press).

Butler, Judith (2009) Frames of War: When Is Life Grievable? (London: Verso).

Caracciolo, Marco (2014) The Experientiality of Narrative: An Enactivist Approach (Berlin: De Gruyter).

Caracciolo, Marco, Cécile Guédon, Karin Kukkonen, and Sabine Müller (2017) "The Promise of an Embodied Narratology: Integrating Cognition, Representation and Interpretation," in Per Krogh Hansen, John Pier, Philippe Roussin, and Wolf Schmid (eds.) Emerging Vectors of Narratology,ed. (Berlin: De Gruyter, 2017), pp. 435-460.

Chouliaraki, Lilie (2010) "Ordinary Witnessing in Post-Television News: Towards a New Moral Imagination," Critical Discourse Studies 7.3, pp. 305-319.

Garber, Marjorie (2004) "Compassion," in Lauren Berlant (ed.) Compassion: The Culture and Politics of an Emotion, (New York: Routledge), pp. 15-29.

Hadžić, Kemal (1998) Sarajevo '94 (Sarajevo: Međunarodni centar za mir).

Hammond, Philip (2004) "Humanizing War. The Balkans and Beyond," in Stuart Allan and Barbie Zelizer (eds.) Reporting War: Journalism in Wartime, (London: Routledge), pp. 174-189.

Jergović, Miljenko (2015) Sarajevo, plan grada (Zagreb: Fraktura).

Jurecic, Ann (2011) "Empathy and the Critic," College English 74.1, pp. 10-27.

Koopman, Eva Maria (2015) "Empathic Reactions after Reading: The Role of Genre, Personal Factors and Affective Responses," Poetics 50, pp. 62-79.

Koopman, Eva Maria (2018) "Does Originality Evoke Understanding? The Relation Between Literary Reading and Empathy," Review of General Psychology 22.2, pp. 169-177.

Kovačević, Milomir (2012) Sarajevo: ma ville, mon destin, Photographies de Milomir Kovačević; textes de François Maspero, Andrea Lešić et Milomir Kovačević (Paris: Actes Sud). 
Kukkonen, Karin and Marco Caracciolo (2014) "Introduction: What is the 'Second Generation'?," Style 48.3, pp. 261-274.

Lazarevska, Alma (2014) Death in the Museum of Modern Art. Trans. Celia Hawkesworth (London: Istros Books).

Lešić, Andrea (2016) “Milomir Kovačević’s War Photographs: How Not to Dehumanise a Traumatised Subject," in Tanja Zimmermann and Aleksandar Jakir (eds.) Europe and the Balkans: Decades of “Europeanization”? (Würzburg: Königshausen \& Neumann), pp. 137-152.

Lux, Vanessa and Sigrid Weigel (eds.) (2017) Empathy: Epistemic Problems and Cultural-Historical Perspectives of a Cross-Disciplinary Concept (London: Palgrave MacMillan).

Maček, Ivana (2009) Sarajevo Under Siege: Anthropology in Wartime: The Ethnography of Political Violence (Philadelphia: University of Pennsylvania Press).

Mehmedinović, Semezdin (1998a) "Fotografije Kemala Hadžića - Sarajevo '94," in Kemal Hadžić (ed.) Sarajevo '94, (Sarajevo: Međunarodni centar za mir), pp. 5-11.

Mehmedinović, Semezdin (1998b) Sarajevo Blues. Trans. Ammiel Alcalay (San Francisco: City Lights Books).

Otašević, Mira (2012) Zoja (Belgrade: Geopoetika).

Robinson, Douglas (2008) Estrangement and the Somatics of Literature: Tolstoy, Shklovsky, Brecht (Baltimore: Johns Hopkins University Press).

Rothberg, Michael (2009) Multidirectional Memory: Remembering the Holocaust in the Age of Decolonization (Stanford: Stanford University Press).

Rothberg (2013) "Multidirectional Memory and the Implicated Subject: On Sebald and Kentridge," in Liedeke Plate and Anneke Smelik (eds.) Performing Memory in Art and Popular Culture (New York: Routledge), pp. 39-58.

Ruigrok, Nel (2008) "Journalism of Attachment and Objectivity: Dutch Journalists and the Bosnian War," Media, War \& Conflict 1.3, pp. 293-313.

Shklovsky, Viktor and Alexandra Berlina (2017) Viktor Shklovsky: A Reader, trans. and introd. Alexandra Berlina (New York: Bloomsbury Academic).

Shklovsky, Viktor (2017) “Art as Device” [1 ${ }^{\text {st }}$ edn 1917/1919], trans. Alexandra Berlina, Viktor Shklovsky: A Reader (New York: Bloomsbury Academic), pp. 73-96.

Snel, Guido (2016) “'My Dream Can Also Become Your Burden’: Semezdin Mehmedinović’s Poetics of Self-Determination," in Andrew Hammond (ed.) The Novel and Europe (Basingstoke: Palgrave MacMillan), pp. 227-242.

Sontag, Susan (2003) Regarding the Pain of Others (New York: Picador).

Spolsky, Ellen (1996) “Elaborated Knowledge: Reading Kinesis in Pictures," Poetics Today 17.2, pp. $157-180$.

Oppen, Karoline Von (2009) "Reporting from Bosnia: Reconceptualising the Notion of a 'Journalism of Attachment', Journal of Contemporary European Studies 17.1, pp. 21-33.

Weigel, Sigrid (2017) “The Heterogeneity of Empathy," in Vanessa Lux and Sigrid Weigel (eds.) Empathy: Epistemic Problems and Cultural-Historical Perspectives of a Cross-Disciplinary Concept (London: Palgrave MacMillan), pp. 1-23.

Zelizer, Barbie (2010) About to Die: How News Images Move the Public (Oxford: Oxford University Press). 
